\title{
Lack of specificity of antibodies directed against human beta-adrenergic receptors
}

\author{
Nazha Hamdani • Jolanda van der Velden
}

Received: 18 November 2008 / Accepted: 2 January 2009 / Published online: 22 January 2009

(C) The Author(s) 2009. This article is published with open access at Springerlink.com

\begin{abstract}
The present study was designed to investigate if antibodies against $\beta$-adrenergic receptors ( $\beta$ ARs) can be used to determine expression of $\beta A R$ in human myocardium. Western blotting was performed to investigate the specificity of antibodies directed against $\beta_{1} \mathrm{AR}$ and $\beta_{2} \mathrm{AR}$ in human left ventricular tissue. A comparison was made between cardiac tissue from patients with idiopathic dilated cardiomyopathy and ischemic heart disease and nonfailing donors. The antibodies directed against $\beta_{1} \mathrm{AR}$ and $\beta_{2} \mathrm{AR}$ recognized several protein bands at different molecular weights. Moreover, both antibodies also recognized multiple proteins in Chinese hamster ovary cells expressing $\beta_{1} \mathrm{AR}, \beta_{2} \mathrm{AR}$, and even $\beta_{3} \mathrm{AR}$. $\beta \mathrm{AR}$ antibodies are not specific and are not suited to study expression of $\beta A R$ in human myocardium.
\end{abstract}

Keywords Beta-1 adrenoceptor - Beta-2 adrenoceptor . Antibody $\cdot$ Selectivity

\section{Introduction}

The $\beta$-adrenergic pathway is activated upon an increase in catecholamine levels. Binding of catecholamines to the $\beta$ -

\footnotetext{
N. Hamdani $(\bowtie) \cdot J$. van der Velden

Laboratory for Physiology, Institute for Cardiovascular Research,

VU University Medical Center,

van der Boechorststraat 7,

1081 BT Amsterdam, The Netherlands

e-mail: nazha.hamdani@vumc.nl
}

adrenergic receptors ( $\beta$ ARs) increases contractility of the cardiomyocytes via protein-kinase-A-mediated phosphorylation of downstream target proteins involved in calcium handling (Hasenfuss and Fieske 2002) and myofilament contraction (Solaro et al. 1976). In the human myocardium, at least three types of $\beta$ ARs are present, including $\beta_{1} A R$, $\beta_{2} A R$, and $\beta_{3} A R$ (Brodde 2007). Analysis of $\beta A R s$ in crude membrane fractions using radioligand binding studies revealed a ratio of $80: 20$ for $\beta_{1} A R$ and $\beta_{2} A R$ in nonfailing human donor tissue (Brodde 2007), with $\beta_{1} A R$ as the predominant receptor. In failing idiopathic dilated cardiomyopathy (IDCM) myocardium, a downregulation of $\beta_{1} \mathrm{AR}$ has been observed, leading to a relative increase in $\beta_{2} \mathrm{AR}$, as illustrated by the altered ratio of $\beta_{1} \mathrm{AR}$ and $\beta_{2} \mathrm{AR}$ to 60:40 in the failing heart (Brodde 2007; Bristow et al. 1986, 1989). Diverse alterations in myocardial $\beta A R$ density have been reported in IDCM and ischemic heart disease (ISHD) patients (Bristow et al. 1991; Steinfath et al. 1991). In failing IDCM myocardium, a downregulation of $\beta_{1}$ AR has been observed (Bristow et al. 1991), while $\beta_{2} \mathrm{AR}$ remained unchanged (Steinfath et al. 1991). In contrast, a reduction of both $\beta_{1} \mathrm{AR}$ and $\beta_{2} \mathrm{AR}$ was reported in ISHD patients (Steinfath et al. 1991; Bristow et al. 1986, 1989).

Apart from radioligand binding studies, Western blotting is often used to determine expression levels of $\beta A R$. The present study was designed to investigate specific binding of antibodies directed against $\beta_{1} \mathrm{AR}$ and $\beta_{2} \mathrm{AR}$ in different human heart samples. Left ventricular (LV) tissue from patients with IDCM and ISHD was compared with nonfailing donor myocardium. Moreover, specific binding of $\beta A R$ antibodies was investigated in Chinese hamster ovary (CHO) cells expressing human $\beta$ ARs (Niclauss et al. 2006). 


\section{Methods and materials}

Human ventricular tissue

LV transmural tissue samples were obtained during heart transplantation surgery from end-stage heart failure patients (NYHA III-IV) with IDCM $(n=21)$ and ISHD $(n=19)$. LV tissue from donor hearts $(n=10)$ served as reference for nonfailing myocardium. Tissue was collected in cardioplegic solution and stored in liquid nitrogen. Samples were obtained after informed consent and with approval of the local Ethical Committee (St Vincent's Hospital Human Research Ethics Committee: File number: H03/118; Title: Molecular Analysis of Human heart Failure).

\section{Cell culture}

Our experiments are based on $\mathrm{CHO}$ cells expressing either the human $\beta_{1} \mathrm{AR}, \beta_{2} \mathrm{AR}$, or $\beta_{3} \mathrm{AR}$ at densities $\left(B_{\max }\right)$ of $118 \pm 28,202 \pm 27$, and $199 \pm 59 \mathrm{fmol} / \mathrm{mg}$ proteins as previously described (Niclauss et al. 2006). CHO cells were stably transfected with human $\beta A R$ subtypes using a pSW104 vector and grown in an atmosphere of 5\% $\mathrm{CO}_{2} /$ $95 \%$ air at $37^{\circ} \mathrm{C}$ in F-12 HAM medium supplemented with $10 \%$ heat-inactivated fetal calf serum, $1 \mathrm{mM}$ glutamine, $100 \mathrm{U} / \mathrm{ml}$ penicillin, and $0.1 \mathrm{mg} / \mathrm{ml}$ streptomycin. Subconfluent cells were subcultured every 3-4 days with a $2.5 \mathrm{~g} / 1$ trypsin and $0.2 \mathrm{~g} / 1 \mathrm{Na}_{4}$ EDTA solution. To maintain selection pressure, the antibiotic G418 (400 $\mathrm{mg} / \mathrm{ml})$ was added to all growing cells in regular intervals but was not present during the experiments. For all experiments, the cells were cultured in the absence of serum for $24 \mathrm{~h}$ preceding the experiments to avoid interference of serum factors with cell growth and related signal transduction.

\section{Detection of $\beta$ ARs}

\section{Antibodies against $\beta_{1} A R$ and $\beta_{2} A R$}

Two different primary rabbit polyclonal antibodies directed against the $\beta_{1} \mathrm{AR}$ and $\beta_{2} \mathrm{AR}$ were used for Western blotting. Both antibodies were from Santa Cruz $\left(\beta_{1} A R\right.$ (V-19): catalog: sc-568; $\beta_{2} \mathrm{AR}$ (H-73): catalog: sc-9042). The antibody directed against $\beta_{1} \mathrm{AR}$ was raised against amino acids $420 \mathrm{t}-470$ at the $\mathrm{C}$-terminus of $\beta_{1} \mathrm{AR}$ of mouse origin, while the $\beta_{2} \mathrm{AR}$ antibody was raised against amino acids 338-413 mapping at the C-terminus of the $\beta_{2} A R$ of human origin.

\section{Western blotting}

Protein expression levels of $\beta_{1} \mathrm{AR}$ and $\beta_{2} \mathrm{AR}$ were analyzed by one-dimensional $15 \%$ sodium dodecyl sulfate
(SDS)-polyacrylamide gel electrophoresis (1D-PAGE) and subsequent Western blotting. Cardiac tissue homogenates (in sample buffer containing 15\% glycerol, $62.5 \mathrm{mmol} / 1$ Tris (pH 6.8), 1\% (w/v) SDS, and 2\% (w/v) dithiothreitol) were applied in a concentration, which was within the linear range of detection: $20 \mu \mathrm{g}$ protein per lane for $\beta_{1} \mathrm{AR}$ and $\beta_{2} \mathrm{AR}$. After 1D separation, proteins were transferred to Hybond-ECL nitrocellulose membranes. Blots were preincubated with $0.5 \%$ milk powder in Tween-Tris-buffered saline (TTBS; $10 \mathrm{mmol} / \mathrm{l}$ Tris- $\mathrm{HCl} \mathrm{pH}$ 7.6, $75 \mathrm{mmol} / \mathrm{l}$ $\mathrm{NaCl}, 0.1 \%$ Tween) for $1 \mathrm{~h}$ at room temperature. The blots were incubated overnight at $4^{\circ} \mathrm{C}$ with primary rabbit polyclonal antibodies against $\beta_{1} \mathrm{AR}$ (dilution 1:200) and $\beta_{2}$ AR (dilution 1:200). After washing with TTBS, primary antibody binding was visualized using a secondary horseradish-peroxidase-labeled goat antirabbit antibody (dilution 1:2,000; DakoCytomation) and enhanced chemiluminescence (ECL plus Western blotting detection, Amersham Biosciences). All signals were normalized to actin (dilution 1:1,000; clone KJ43A; Sigma) stained on the same blots.

\section{Results}

Detection of $\beta$ ARs in human myocardium

Figure 1a shows Western blots of failing and nonfailing cardiac samples. The antibodies against $\beta_{1} \mathrm{AR}$ and $\beta_{2} \mathrm{AR}$ recognized multiple bands at different molecular weights (Fig. 1a). A similar pattern of protein bands was obtained when we replaced milk by albumin (bovine serum albumin $2 \%$ ) as blocking agent (not shown). The molecular weight of the detected protein bands was calculated on the basis of the molecular weight marker (Precision Plus Protein Standards Dual Color).

The most prominent band visualized upon $\beta_{1} \mathrm{AR}$ labeling was observed at $33 \mathrm{kDa}$, and two more faint bands of higher molecular weight were found. All of these were no longer visible in the presence of blocking peptide against $\beta_{1}$ AR (dilution 1:200; sc-568p; Santa Cruz; Fig. 1b).

The $\beta_{2} A R$ antiserum recognized a large number of bands among which those at 32,48 , and $75 \mathrm{kDa}$ were most prominent. None of the detected protein bands corresponded with the predicted molecular weight of the $\beta_{2} \mathrm{AR}$, which is $\sim 65 \mathrm{kDa}$.

Immunoreactivity levels of different protein bands detected by the $\beta A R$ antibodies were expressed relative to actin expression. Bar graphs are shown in Fig. 1c for the mean data (sum of all signals obtained with antibodies directed against $\beta A R$ ) obtained in IDCM and ISHD samples in comparison to donor myocardium, which was set to 1 . One-way analysis of variance revealed no significant differences in the immunoreactivity of $\beta_{1} \mathrm{AR}$ and $\beta_{2} \mathrm{AR}$ between all groups. 
Fig. 1 Western blot staining a of failing $(F)$ and nonfailing $(N F)$ cardiac samples separated by $1 D-P A G E$. Figure a illustrates protein bands (indicated by arrows) detected by antibodies against $\beta_{1} \mathrm{AR}$ and $\beta_{2} \mathrm{AR}$. Molecular weight of the protein bands was calculated on the basis of the molecular weight marker $(\mathrm{mwm})$. The predicted molecular weight for the $\beta$ ARs is shown in bold. b Western blots incubated with $\beta_{1} \mathrm{AR}$ antibody without blocking peptide (left panel) and with blocking peptide (right panel) of $\mathrm{F}$ and NF samples. c Analysis of $\beta$ ARs revealed no significant differences between IDCM, ISHD, and NF donor myocardium
Fig. 2 Western blots illustrating the binding of antibodies directed against $\beta_{1} A R$ and $\beta_{2} A R$ in failing and nonfailing human samples and $\mathrm{CHO}$ cells expressing $\beta_{1} \mathrm{AR}, \beta_{2} \mathrm{AR}$, and $\beta_{3} \mathrm{AR}$

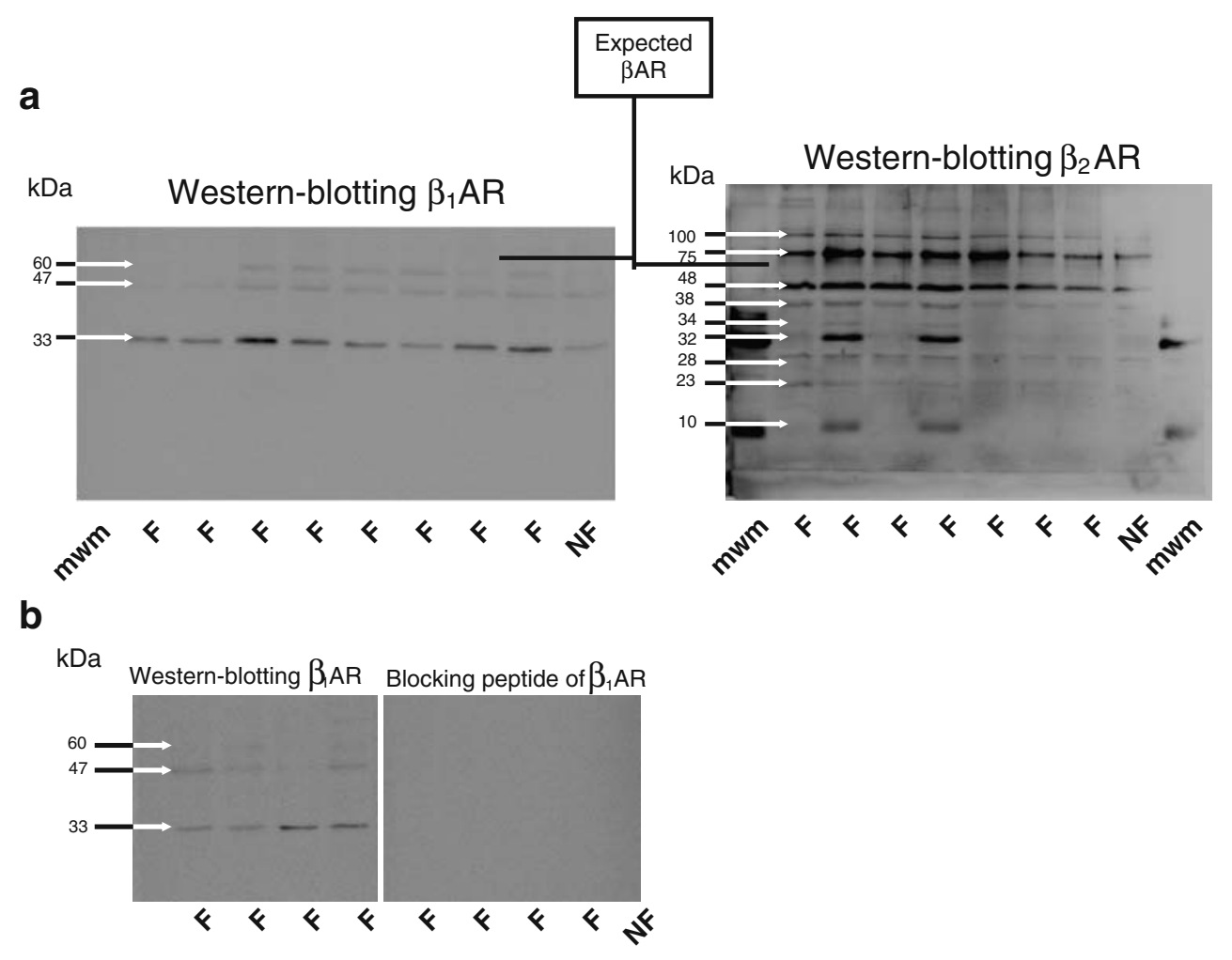

C
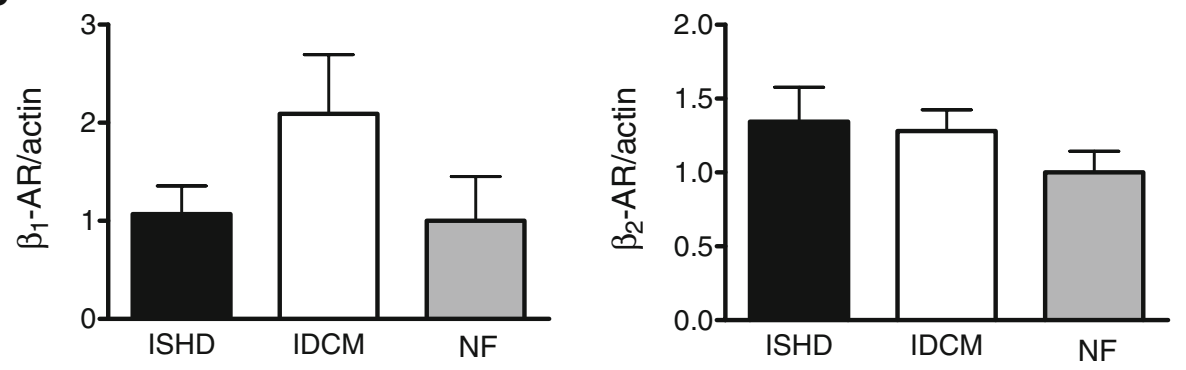
Analysis of $\beta$ ARs in $\mathrm{CHO}$ cells

Subsequently, specificity of antibodies directly against $\beta_{1} \mathrm{AR}$ and $\beta_{2} \mathrm{AR}$ was tested in $\mathrm{CHO}$ cells expressing $\beta_{1} \mathrm{AR}, \beta_{2} \mathrm{AR}$, and $\beta_{3} \mathrm{AR}$ (Fig. 2). In addition, failing and nonfailing samples were used as controls. The antibodies directed against $\beta_{1} \mathrm{AR}$ and $\beta_{2} \mathrm{AR}$ all recognized several protein bands with molecular weights ranging between 25 and $120 \mathrm{kDa}$ in $\mathrm{CHO}$ cells expressing $\beta_{1} \mathrm{AR}, \beta_{2} \mathrm{AR}$, and even $\beta_{3} A R$, while no band was observed at the expected molecular weight of $\sim 65 \mathrm{kDa}$. All protein bands stained with the $\beta_{1}$ AR antibody disappeared in the presence of the blocking peptide against $\beta_{1} \mathrm{AR}$ (not shown).

\section{Discussion}

Most of the antibodies known to interact with $\beta$ ARs described in the literature did not exhibit subtype selectivity (Moxham et al. 1986; Dixon et al. 1986; Kaveri et al. 1987). Moxham et al. (1986) investigated $\beta_{1}$ ARs and $\beta_{2}$ ARs in membrane preparations from rat lung and rat heart, respectively, and observed that antibodies directed against $\beta_{1} \mathrm{AR}$ and $\beta_{2} \mathrm{AR}$ interacted with both receptor subtypes. In these previous studies, antibodies were raised against isolated receptor subtypes, while the antibodies used in our study were directed against a peptide sequence, which might increase their selectivity.

Our study shows that antibodies directed at a specific part of the $\beta A R s$ are still not specific and do not allow determination of $\beta A R$ expression levels since both antibodies detected a range of protein bands at different molecular weights in failing and nonfailing human cardiac samples. It is noteworthy that no bands were observed at the predicted molecular weight of $65 \mathrm{kDa}$. Several studies have shown that the $65-\mathrm{kDa}$ subunit exists in a dimeric form in the cell membrane, with a molecular size of $109 \mathrm{kDa}$ as determined by immunoaffinity chromatography using monoclonal autoantibodies and SDS-polyacrylamide gels (Boivin et al. 2006; Fraser and Venter 1982). We did not find evidence for a dimeric form in our study using the $\beta_{1} \mathrm{AR}$ and $\beta_{2} \mathrm{AR}$ antibodies.

It has been proposed that the different bands detected upon $\beta A R$ antibody binding represent different forms of the $\beta$ ARs resulting from complex formation and/or posttranslational modifications such as glycosylation as described by Rybin et al. (2000). Both antibodies against $\beta_{1} \mathrm{AR}$ and $\beta_{2} \mathrm{AR}$ detected a band with a molecular weight of $75 \mathrm{kDa}$ in all samples. Glycosylation may alter molecular weight of $\beta$ ARs by 8 to $11 \mathrm{kDa}$ (George et al. 1986), and hence it is possible that the band detected at $75 \mathrm{kDa}$ is the putative $\beta \mathrm{AR}$.
Based on the assumption that all signals represent different forms of $\beta$ ARs, we averaged the sum of all $\beta A R$ signals for the different cardiac samples. No significant difference was observed in $\beta$ AR expression level (sum of all $\beta$ AR signals relative to actin) between failing and nonfailing samples. It should be noted that tissue preparation might have interfered with analysis of $\beta A R$ expression. In the present study, expression of $\beta_{1} A R$ and $\beta_{2} A R$ was determined in whole cardiac homogenates and therefore lacks information about receptor density at the membranes (i.e., functionally available receptors for ligand binding). However, the fact that multiple protein bands were stained with both $\beta_{1} \mathrm{AR}$ and $\beta_{2} \mathrm{AR}$ antibodies in $\mathrm{CHO}$ cells expressing $\beta$ ARs, even in cells with the $\beta_{3} A R$, indicates that the antibodies are not specific. Moreover, all protein bands stained with the $\beta_{1}$ AR antibody disappeared in the presence of the blocking peptide against $\beta_{1} A R$, both in tissue and $\mathrm{CHO}$ cells (not shown), illustrating that the Western blot analysis using antibodies directed against $\beta A R$ in combination with a blocking peptide is invalid and cannot be used for quantitative analysis of $\beta A R$ densities.

In conclusion, Western blot analysis cannot be used for quantitative analysis of $\beta A R$ receptors because they do not show specific binding to their target protein. Further investigations have to be performed to clarify the selectivity and specificity of antibodies against $\beta$ AR receptor proteins.

Acknowledgements We thank Prof. Cris dos Remedios (Muscle Research Unit, Institute For Biomedical Research, the University of Sydney, Australia) for the human ventricular tissue samples. We thank Prof. Martin Michel (Dept. Pharmacology and Pharmacotherapy AMC, University of Amsterdam, Amsterdam, the Netherlands) for providing the $\mathrm{CHO}$ cells expressing $\beta$ ARs.

Open Access This article is distributed under the terms of the Creative Commons Attribution Noncommercial License which permits any noncommercial use, distribution, and reproduction in any medium, provided the original author(s) and source are credited.

\section{References}

Boivin B, Lavoie C, Vaniotis G, Baragli A, Villeneuve LR, Ethier N, Trieu P, Allen BG, Hébert TE (2006) Functional beta-adrenergic receptor signalling on nuclear membranes in adult rat and mouse ventricular cardiomyocytes. Cardiovasc Res 71:69-78

Bristow MR, Ginsburg R, Umans V, Fowler M, Minobe W, Rasmussen R, Zera P, Menlove R, Shah P, Jamieson S (1986) Beta 1- and beta 2-adrenergic-receptor subpopulations in nonfailing and failing human ventricular myocardium: coupling of both receptor subtypes to muscle contraction and selective beta 1-receptor down-regulation in heart failure. Circ Res 59:297309 
Bristow MR, Hershberger RE, Port JD, Minobe W, Rasmussen R (1989) Beta 1- and beta 2-adrenergic receptor-mediated adenylate cyclase stimulation in nonfailing and failing human ventricular myocardium. Mol Pharmacol 35:295-303

Bristow MR, Anderson FL, Port JD, Skerl L, Hershberger RE, Larrabee P, O'Connell JB, Renlund DG, Volkman K, Murray J (1991) Differences in beta-adrenergic neuroeffector mechanisms in ischemic versus idiopathic dilated cardiomyopathy. Circulation 84:1024-1039

Brodde OE (2007) Beta-adrenoceptor blocker treatment and the cardiac beta-adrenoceptor-G-protein(s)-adenylyl cyclase system in chronic heart failure. Naunyn Schmiedebergs Arch Pharmacol 374:361-372

Dixon RA, Kobilka BK, Strader DJ, Benovic JL, Dohlman HG, Frielle T, Bolanowski MA, Bennett CD, Rands E, Diehl RE, Mumford RA, Slater EE, Sigal IS, Caron MG, Lefkowitz RJ, Strader CD (1986) Cloning of the gene and cDNA for mammalian beta-adrenergic receptor and homology with rhodopsin. Nature 321:75-79

Fraser CM, Venter JC (1982) The size of the mammalian lung beta 2adrenergic receptor as determined by target size analysis and immunoaffinity chromatography. Biochem Biophys Res Commun 109:21-29

George ST, Ruoho AE, Malbon CC (1986) N-Glycosylation in expression and function of $\beta$-adrenergic receptors. J Biol Chem 261:16559-16564
Hasenfuss G, Pieske B (2002) Calcium cycling in congestive heart failure. J Mol Cell Cardiol 34:951-969

Kaveri SV, Cervantes-Olivier P, Delavier-Klutchko C, Strosberg AD (1987) Monoclonal antibodies directed against the human A431 beta 2-adrenergic receptor recognize two major polypeptide chains. Eur J Biochem 167:449-456

Moxham CP, George ST, Graziano MP, Brandwein HJ, Malbon CC (1986) Mammalian beta 1- and beta 2 -adrenergic receptors. Immunological and structural comparisons. J Biol Chem 261:14562-14570

Niclauss N, Michel-Reher MB, Alewijnse AE, Michel MC (2006) Comparison of three radioligands for the labelling of human $\beta$ adrenoceptor subtypes. Naunyn-Schmiedeberg's Arch Pharmacol 374:99-105

Solaro RJ, Moir AJ, Perry SV (1976) Phosphorylation of troponin I and the inotropic effect of adrenaline in the perfused rabbit heart. Nature. 262:615-617

Steinfath M, Geertz B, Schmitz W, Scholz H, Haverich A, Breil I, Hanrath P, Reupcke C, Sigmund M, Lo HB (1991) Distinct down-regulation of cardiac beta 1- and beta 2-adrenoceptors in different human heart diseases. Naunyn Schmiedebergs Arch Pharmacol 343:217-220

Rybin VO, Xu X, Lisanti MP, Steinberg SF (2000) Differential targeting of beta -adrenergic receptor subtypes and adenylyl cyclase to cardiomyocyte caveolae A mechanism to functionally regulate the cAMP signaling pathway. J Biol Chem 275:4144741457 